\title{
Impact of spraying chitosan and turmeric extract on fruiting of Flame seedless grapevines
}

\author{
Mahmoud M. Refaai ${ }^{1}$ and Ahmed A.E.M. Silem ${ }^{2} *$ \\ 1- Organic Farming central Lab. ARC, Giza, Egypt. \\ 2- Hort. Dept. Fac. of Agric. Al- Azhar Univ. (Assiut branch) - Egypt. \\ *Corresponding author: $\underline{\text { dr.ahmadsilem@gmail.com }}$
}

Submitted October 13, 2021; Accepted November 8, 2021; Published November 21, 2021

\section{SUMMARY}

During 2020 and 2021 seasons, Flame seedless grapevines were sprayed three times at growth start, just, after berry setting and one month later with chitosan at 0.025, 0.05 and $0.1 \%$ and turmeric extract at $0.1,0.2$ and $0.3 \%$ as single or combined application examining the effect of these treatments on growth, vine nutritional status, berry setting \%, yield as well as berry colouration and quality. Single and combined applications of chitosan and turmeric extract had an obvious promotion on some growth aspects, vine nutritional status, berry setting, yield, berry colouration $\%$ and quality of the berry relative to the control treatment. Combined applications were superior than using each material alone.

Using chitosan was considerably favourable than using turmeric extract in improving some growth, vine nutritional status, berry setting, yield, berry colouration and berry quality. A slight promotion on these characteristics was observed among the higher two concentrations of chitosan namely 0.05 to $0.1 \%$ and turmeric extract namely 0.2 to 0.3. Carrying out spraying of a mixture chitosan at $0.05 \%$ and turmeric extract at $0.2 \%$ at growth start, just after berry setting and one month later was responsible for improving yield and berry quality of Flame seedless grapevines grown under Minia region conditions

\section{Keywords: Flame seedless grapevines, chitosan, turmeric extract, berry setting, berry colouration, yield. INTRODUCTION}

Abiotic stress caused by higher temporarily on Flame seedless grapevines grown under El- Minia environmental conditions resulted in poor yield and berry colourations. Many efforts were done for findings out the recent and non- traditional horticultural practices that are responsible for solving these defects. Out of these practices was the application of chitosan and turmeric extract an essential antioxidant required for the trees grown under unfavourable environmental conditions. Chitosan (acetyl glucosamine) is a natural biopolymer combined derived.

Therefore, the idea of using chitosan as a promising and new natural compound for overcoming of these problems was raised. Chitosan is considered a biopolymer produced from chitin and is very safe for human being. It has bioactivity and bio compatibility (Dias et al., 2013).

Using it in plants resulted in improving the yield and reducing transpiration (Mondal et al., 2012).

It is an important antioxidant and using it was accompanied with blocking oxygen species (ROS) and protecting the vines from their damages (Parl et al., 2004).

The plants subjected to chitosan are less prone of all biotic and abiotic stresses (Jabeen and Ahmad, 2013 and Pongrayoon et al., 2013).

It contains $2 \%$ of chitosan (Poly- Dgklucsamien) which is one of the most common polymers found in nature (Wojdyla, 2001).
Chitosan is structurally related to cellulose, which consists of long chain of glucose molecules linked to each other. In chitosan, the building block of the chain is slightly modified from of glucose (Wojdyla, 2001).

Moreover, plants treated with chitosan may be less prone to stress evoked by unfavourable conditions such as drought, salinity, low or high temperature (Lin et al., 2005; Liu et al., 2007; Xu et al., 2007 and Shao et al., 2015).

Turmeric is the dried rhizome of the plant curcuma Longa $\mathrm{L}$. It is used in various industrial purposes, medicine, religious functions and as biopesticide. The genus curcuma belongs to the family Zingiberaceae and contains 49 genera and 1400 species. Turmeric is an erect perennial herb, grown as an annual crop. The above ground of the plant is an erect pseudostem bearing leaves and inflorescences (Govinarajan, 1980).

Turmwric is valued mainly for its principel a coloyuring pigments, curcumin which imparts the yellow colour to turmeric, besides nutritive contituents like potassium.

Curcumindemethocycucrumin, methone and bisdemethoxycurcumin together make the colouring pigments in the turmeric rhizomes (Peter, 1999).

The goal of this study as elucidating the effect of chitosan and/ or turmeric extract on growth aspects, vine nutritional status, berry setting \%, yield, berry colouration $\%$ and quality of Flame seedlings grapes. 


\section{MATERIALS AND METHODS}

This study was carried out during the two consecutive seasons of 2020 and 2021 on sixteen uniform in vigour own rooted 14 years old of grapevines cvs Flame seedless, grown in a private vineyard, situated at Talla village, Minia district, Minia Governorate, Egypt, where the texture of the soil is clay. Well drained and water table not less than two meters deep. All the selected vines are planted at $1.5 \times 3.0$ meters apart (888 vines/ fed.). The chosen vines were pruned during the last week of December in both seasons using sour pruning method. Vine load was 72 eyes for all the selected vines on the basis of (12 fruiting spurs $\mathrm{x} 5$ eyes plus six replacement spurs $\mathrm{x}$ two eyes) using Gable supporting method. Surface irrigation system was followed using Nile water containing 160 ppm salinity.

Mechanical, physical and chemical analysis of the tested soil were carried out at the start of the experiment according to the procedures of Wilde $e t$ al., (1985) and the results are shown in the Table (1).

Table (1): Analysis of the tested vineyard soil

\begin{tabular}{llll}
\hline $\begin{array}{l}\text { Parameters } \\
\text { Particle size distribution }\end{array}$ & Values & $\begin{array}{l}\text { Parameters } \\
\text { Macronutrients }\end{array}$ & Values \\
\hline Sand \% & 8.5 & Total N\% & 0.09 \\
Silt \% & 14.0 & $\mathrm{P}(\mathrm{ppm})$ & 4.11 \\
Clay \% & 77.5 & $\mathrm{~K}(\mathrm{ppm})$ & 420 \\
Texture grade & Clay & $\mathrm{Mg}(\mathrm{ppm})$ & 6.15 \\
pH $(1: 2.5$ extract) & 7.58 & EDTA extractable micronutrients & \\
EC $\left(1: 2.5\right.$ extract) mmhos $/ 1 \mathrm{~cm} 25^{\circ} \mathrm{C}$ & 0.79 & Fe (ppm) & 1.15 \\
M.O. $\%$ & 2.11 & $\mathrm{Zn}(\mathrm{ppm})$ & 0.81 \\
$\mathrm{CaCO}_{3} \%$ & 2.4 & $\mathrm{Mn}(\mathrm{ppm})$ & 1.99 \\
\hline
\end{tabular}

Except these dealing with the present treatments (chitosan and turmeric extract), all the selected vines (60 vines) received the usual horticultural practices which are commonly used in the vineyard. This study included the following ten treatments from chitosan and turmeric extract.

1- Control.

2- Spraying chitosan at $0.025 \%$ (1/4 g / L.)

3- Spraying chitosan at $0.05 \%(1 / 2 \mathrm{~g} / \mathrm{L}$. $)$

4- Spraying chitosan at $0.1 \%(1 \mathrm{~g} / \mathrm{L}$. $)$

5- Spraying turmeric extract at $0.1 \%(1 \mathrm{~g} / \mathrm{L}$.)

6- Spraying turmeric extract at $0.2 \%(2 \mathrm{~g} / \mathrm{L}$.)

7- Spraying turmeric extract at $0.3 \%$ ( $3 \mathrm{~g} / \mathrm{L}$.)

8- Spraying chitosan at $0.025 \%+$ turmeric extract at $0.1 \%$.

9- Spraying chitosan at $0.05 \%+$ turmeric extract at $0.2 \%$.
10-Spraying chitosan at $0.1 \%+$ turmeric extract at $0.2 \%$.

Each treatment was replicated three times, two vines per each. The total vines selected for achieving this experiment was 60 vines. Chitosan and turmeric extract were sprayed three times at growth start (first week of March), just after berry setting (first week of Apr.) and at one month later (first week of May). Chitosan was sprayed amounts was dissolved in few drops of $0.1 \mathrm{~N} \mathrm{NaOH}$ for facilitating the solubility.

Triton B was added to $0.1 \%$ few drops of $0.1 \mathrm{~N}$ $\mathrm{NaOHwas}$ added to the known weights of chitosan to facilitate the solubility. Spraying was done till run off.

Randomized complete block design (RCBD) was followed.

Table (2): Chemical composition of turmeric extract (according to Shiyouet al., 2011)

\begin{tabular}{llll}
\hline Compounds & Values/ 100 g. D.W. & Compounds & Values 100 g. D.W. \\
\hline$\beta$ - Bisabolene \% & 1.3 & $\alpha$-Pinene \% & 0.1 \\
$1 / 8-$ cineol \% & 2.4 & Terpinolene \% & 0.3 \\
P- cymene \% & 3.0 & Tr- turmerone \% & 31.1 \\
P- cymen-8- ol \% & 0.3 & Turmerone \% & 10.0 \\
Tr- curcumin \% & 6.3 & Ascorbic acid $(\mathrm{mg})$ & 50.0 \\
Curlone \% & 10.6 & ASH $(\mathrm{g})$ & 6.8 \\
Dehydrocucumin \% & 2.2 & Calcium $(\mathrm{g})$ & 0.2 \\
Myrcene \% & 0.1 & Carbohydrate $(\mathrm{g})$ & 69.9 \\
$\alpha-$-Phellandrene $\%$ & 0.1 & Fat $(\mathrm{g})$ & 8.9 \\
\hline
\end{tabular}

During the two seasons, the following measurements were recorded:

- Shoot length (cm), number of leaves/ shoot (leaf) and leaf area $(\mathrm{cm})^{2}$ was calculated as a result of measuring the diameter of twenty mature laves from those apposite to the basal clusters on the main shoots according to Ahmed and Morsy, (1999).
- Leaf pigments namely chlorophyll a, chlorophyll $\mathrm{b}$, total chlorophylls and total carotenoids (mg/ $1.0 \mathrm{~g}$ F.W.) according to Von- Wettstein, (1957).

- Percentages of N, P and K in the leaves (summer, 1985 and Chapman and Pratt, (1987).

- Berry setting \%: It was calculated by caging five clusters per vine in perforated white peper bags 
before blooming stage. At the end of berry setting stage. The bags were removed for counting the following : a-The number of attached berries , (b) The number of dropped berries (c) The number of dropped flowers, (d) the number of total flowers $(\mathrm{a}+$ $b+c)$ per cluster. yield expressed in number of clusters per vine and weight (kg.) vine, cluster weight (g.) berry weight (g.) and dimensions (length and diameter in $\mathrm{cm}$ )

\section{RESULTS AND DISCUSSION}

\section{Vegetative growth:}

It is clear from obtained data Table (3) that treating the vines three times with chitosan and/ or turmeric extract significantly enhanced three shootlength, number of leaves per shoot and leaf area relative to the control. The promotion was associated with increasing concentrations of chitosan from 0.025 to $0.1 \%$ and turmeric extract from 0.1 to $0.3 \%$ combined applications of chitosan and turmeric extract significantly increased these growth aspects than using each material alone. Using chitosan was significantly superior than using turmeric extract in stimulating these growth traits. Increasing concentrations of chitosan from 0.05 to $0.1 \%$ and turmeric extract from 0.2 to $0.3 \%$ had no significant promotion on these growth traits.

The maximum values of shoot length (124.5, $125.0 \mathrm{~cm})$ number of leaves/ shoot $(27.0,28.0)$ and leaf area $\left(127.2,127.8 \mathrm{~cm}^{2}\right)$ were recorded on the vines that received three sprays of a mixture of chitosan at $0.1 \%$ and turmeric extract at $0.3 \%$ during both seasons, respectively.

The untreated vines produced the minimum
- Berry colouration \%.

- Chemical characteristics of the berry namely T.S.S. \% , total sugars \% Lane and Eynon, (1965) and total acidity $\%$ as a tartaric acid $/ 100 \mathrm{ml}$ juice A.O.A.C., (2000). Also, TSS/ acid ratio was calculated.

Statistical analysis was done (according to Mead et al., 1993) treatment means were compared using new L.S.D. at $5 \%$.

values of shoot length $(112.0,113.0 \mathrm{~cm})$, number of leaves per shoot (17.0, 17.0 leaf) and leaf area (113.5, $114.0 \mathrm{~cm}^{2}$ ) during both seasons, respectively.

These results were true during both seasons. The beneficial effect of chitosan on enhancing hormones the resistance to diseases, enzyme, antioxidants and microorganisms, levels of ABA which plays a key role in the regulation of water use due to the closure of stomata availability and uptake of water and essential nutrients through adjusting osmotic pressure in plant cells and in descending order water loss transpiration the accumulation of harmful free ridicules (Hadwiger et al., 2002) could explain the present results.

The results of chitosan are harmony with these found by (Hadwiger et al., 2002, Ewise et al., (2006) on sugar beet;Xu et al.,(2007);Hadwiger(2013); Saied and Radwan, (2017) on Succary mango trees and Khalil, (2021) on Flame seedless grapevines.

The essential roles of turmeric extracts on stimulating cell division, the biosynthesis of organic foods and the resistance of plants to all stresses (Singh et al., 2001).

Table (3): Effect of single and combined application of chitosan and turmeric extract on some vegetative growth characters as well as chlorophyll a and chlorophyll b of Flame seedless grapevines during 2020 and 2021 seasons

\begin{tabular}{|c|c|c|c|c|c|c|c|c|c|c|}
\hline \multirow[t]{2}{*}{ Treatment } & \multicolumn{2}{|c|}{$\begin{array}{l}\text { Shoot length } \\
\quad(\mathrm{cm} .)\end{array}$} & \multicolumn{2}{|c|}{$\begin{array}{c}\text { No. of } \\
\text { leaves/ } \\
\text { shoot } \\
\end{array}$} & \multicolumn{2}{|c|}{$\begin{array}{l}\text { Leaf area } \\
\quad(\mathrm{cm})^{2}\end{array}$} & \multicolumn{2}{|c|}{$\begin{array}{c}\text { Chlorophyll } \\
\text { a (mg/ 1.0 g } \\
\text { F.W.) }\end{array}$} & \multicolumn{2}{|c|}{$\begin{array}{c}\text { Chlorophyll } \\
\text { b (mg/ 1.0 g } \\
\text { F.W.) } \\
\end{array}$} \\
\hline & $\underline{2020}$ & $\underline{2021}$ & $\underline{2020}$ & $\underline{2021}$ & $\underline{2020}$ & $\underline{2021}$ & $\underline{2020}$ & $\underline{2021}$ & $\underline{2020}$ & $\underline{2021}$ \\
\hline Control & 112.0 & 113.0 & 17.0 & 17.0 & 113.5 & 114.0 & 1.77 & 1.81 & 1.11 & 1.13 \\
\hline Spraying chitosan at $0.025 \%$ & 118.5 & 119.0 & 21.0 & 21.0 & 118.2 & 119.0 & 1.95 & 1.98 & 1.21 & 1.22 \\
\hline Spraying chitosan at $0.05 \%$ & 121.0 & 122.2 & 22.5 & 23.0 & 122.0 & 122.2 & 2.01 & 2.03 & 1.29 & 1.30 \\
\hline Spraying chitosan at $0.1 \%$ & 121.5 & 123.0 & 23.5 & 24.0 & 122.7 & 123.0 & 2.03 & 2.05 & 1.31 & 1.31 \\
\hline Spraying turmeric extract at $0.1 \%$ & 114.0 & 114.0 & 18.0 & 19.0 & 115.0 & 115.5 & 1.83 & 1.88 & 1.14 & 1.16 \\
\hline Spraying turmeric extract at $0.2 \%$ & 117.0 & 117.5 & 20.0 & 20.5 & 117.5 & 118.0 & 1.92 & 1.95 & 1.19 & 1.20 \\
\hline Spraying turmeric extract at $0.3 \%$ & 118.2 & 119.0 & 20.5 & 21.0 & 118.2 & 118.8 & 1.96 & 1.99 & 1.22 & 1.23 \\
\hline $\begin{array}{l}\text { Spraying chitosan at } 0.025 \%+ \\
\text { turmeric extract at } 0.1 \% \text {. }\end{array}$ & 121.0 & 121.3 & 23.0 & 24.0 & 122.0 & 123.2 & 2.01 & 2.04 & 1.29 & 1.29 \\
\hline $\begin{array}{l}\text { Spraying chitosan at } 0.05 \%+ \\
\text { turmeric extract at } 0.2 \% \text {. }\end{array}$ & 123.2 & 124.0 & 26.5 & 27.0 & 126.4 & 127.0 & 2.13 & 2.16 & 1.36 & 1.37 \\
\hline $\begin{array}{l}\text { Spraying chitosan at } 0.1 \%+ \\
\text { turmeric extract at } 0.3 \%\end{array}$ & 124.5 & 125.0 & 27.0 & 28.0 & 127.2 & 127.8 & 2.15 & 2.18 & 1.38 & 1.39 \\
\hline New L.S.D. at $5 \%$ & 1.1 & 1.0 & 1.1 & 1.1 & 1.2 & 1.1 & 0.06 & 0.05 & 0.03 & 0.02 \\
\hline
\end{tabular}

\section{Leaf chemical composition:}

Data in Tables $(3,4)$ obviously reveal that varying chitosan and turmeric treatments significantly altered the leaf chemical composition namely chlorophyll a, chlorophyll b, total chlorophylls, total carotenoids, N, P and $\mathrm{K}$ in the leaves rather single and combined applications 
significantly were responsible for enhancing these leaf chemical composition relative to the control was a gradual promotion on leaf chemical composition with increasing concentrations of chitosan from 0.025 to $0.1 \%$ and turmeric extract from 0.1 to $0.3 \%$. Using turmeric extract was significantly preferable than using chitosan in enhancing these leaf chemical composition. Using both materials together significantly increased these leaf pigments and nutrients combined to using material alone in enhancing these leaf chemical composition.

Table (4): Effect of single and combined application of chitosan and turmeric extract on total chlorophylls, total carotenoids and percentages of N, P, and $K$ in the leaves of Flame seedless grapevines during 2020 and 2021 seasons

\begin{tabular}{|c|c|c|c|c|c|c|c|c|c|c|}
\hline \multirow{2}{*}{ Treatment } & \multicolumn{2}{|c|}{$\begin{array}{l}\text { Total } \\
\text { chlorophylls }\end{array}$} & \multicolumn{2}{|c|}{$\begin{array}{l}\text { Total } \\
\text { carotenoids }\end{array}$} & \multicolumn{2}{|c|}{ Leaf $\mathbf{N} \%$} & \multicolumn{2}{|c|}{ Leaf $P \%$} & \multicolumn{2}{|c|}{ Leaf K \% } \\
\hline & $\underline{2020}$ & $\underline{2021}$ & $\underline{2020}$ & $\underline{2021}$ & $\underline{2020}$ & $\underline{2021}$ & $\underline{2020}$ & $\underline{2021}$ & $\underline{2020}$ & $\underline{2021}$ \\
\hline Control & 2.88 & 2.94 & 1.20 & 1.21 & 1.66 & 1.67 & 0.16 & 0.17 & 1.16 & 1.17 \\
\hline Spraying chitosan at $0.025 \%$ & 3.16 & 3.20 & 1.29 & 1.30 & 1.75 & 1.75 & 0.25 & 0.26 & 1.25 & 1.26 \\
\hline Spraying chitosan at $0.05 \%$ & 3.30 & 3.33 & 1.36 & 1.37 & 1.79 & 1.82 & 0.33 & 0.34 & 1.31 & 1.33 \\
\hline Spraying chitosan at $0.1 \%$ & 3.34 & 3.36 & 1.38 & 1.39 & 1.81 & 1.85 & 0.36 & 0.37 & 1.33 & 1.34 \\
\hline Spraying turmeric extract at $0.1 \%$ & 2.97 & 3.04 & 1.22 & 1.23 & 1.68 & 1.69 & 0.19 & 0.19 & 1.19 & 1.21 \\
\hline Spraying turmeric extract at $0.2 \%$ & 3.17 & 3.15 & 1.27 & 1.28 & 1.73 & 1.74 & 0.23 & 0.24 & 1.23 & 1.25 \\
\hline Spraying turmeric extract at $0.3 \%$ & 3.18 & 3.22 & 1.29 & 1.30 & 1.75 & 1.76 & 0.24 & 0.26 & 1.25 & 1.26 \\
\hline $\begin{array}{l}\text { Spraying chitosan at } 0.025 \%+ \\
\text { turmeric extract at } 0.1 \% \text {. }\end{array}$ & 3.30 & 3.33 & 1.28 & 1.39 & 1.82 & 1.86 & 0.35 & 0.37 & 1.33 & 1.35 \\
\hline $\begin{array}{l}\text { Spraying chitosan at } 0.05 \%+ \\
\text { turmeric extract at } 0.2 \% \text {. }\end{array}$ & 3.49 & 3.52 & 1.44 & 1.45 & 1.92 & 1.95 & 0.41 & 0.42 & 1.39 & 1.41 \\
\hline $\begin{array}{l}\text { Spraying chitosan at } 0.1 \%+ \\
\text { turmeric extract at } 0.3 \%\end{array}$ & 3.53 & 3.57 & 1.46 & 1.47 & 1.94 & 1.98 & 0.41 & 0.43 & 1.40 & 1.42 \\
\hline New L.S.D. at $5 \%$ & 0.07 & 0.06 & 0.04 & 0.03 & 0.07 & 0.06 & 0.02 & 0.03 & 0.05 & 0.06 \\
\hline
\end{tabular}

No significant differences were observed on these leaf chemical composition among the higher two concentrations of chitosan namely 0.05 and $0.1 \%$ and turmeric extract from 0.2 and $0.3 \%$. Treating the vines with chitosan at $0.1 \%$ and turmeric extract at $0.3 \%$ gave the maximum values of chlorophyll a
(2.15, $2.18 \mathrm{mg} / 1.0$ g F.W.), chlorophyll b ( 1.38 , $1.39 \mathrm{mg} / 1.0 \mathrm{~g}$ F.W.), total chlorophylls ( $3.53,3.57$ $\mathrm{mg} / 1.0 \mathrm{~g} \mathrm{~F} . \mathrm{W}$.$) , total carotenoids (1.46,1.47 \mathrm{mg} /$ 1.0 g F.W.,N (1.94, 1.98\%), P ( 0.41, 0.43\%) and K ( $1.40,1.42 \%)$ during both seasons respectively. The lowest values were recorded on untreated vines.

Table (5): Effect of single and combined application of chitosan and turmeric extract on the percentages of berry setting, yield as well as cluster weight of Flame seedless grapevines during 2020 and 2021 seasons

\section{Treatment}

Control

Spraying chitosan at $0.025 \%$

Spraying chitosan at $0.05 \%$

Spraying chitosan at $0.1 \%$

Spraying turmeric extract at $0.1 \%$

Spraying turmeric extract at $0.2 \%$

Spraying turmeric extract at $0.3 \%$

Spraying chitosan at $0.025 \%+$ turmeric extract at $0.1 \%$.

Spraying chitosan at $0.05 \%+$ turmeric extract at $0.2 \%$.

Spraying chitosan at $0.1 \%+$ turmeric extract at $0.3 \%$

New L.S.D. at $5 \%$

\begin{tabular}{llllllll}
\multicolumn{2}{c}{$\begin{array}{c}\text { Berry setting } \\
\text { \% }\end{array}$} & \multicolumn{2}{c}{$\begin{array}{c}\text { No. of clusters } \\
\text { / vine }\end{array}$} & \multicolumn{2}{c}{$\begin{array}{c}\text { Cluster weight } \\
\text { (g.) }\end{array}$} & \multicolumn{2}{c}{$\begin{array}{c}\text { Yield per vine } \\
\text { (kg.) }\end{array}$} \\
\hline$\underline{\mathbf{2 0 2 0}}$ & $\underline{\mathbf{2 0 2 1}}$ & $\underline{\mathbf{2 0 2 0}}$ & $\underline{\mathbf{2 0 2 1}}$ & $\underline{\mathbf{2 0 2 0}}$ & $\underline{\mathbf{2 0 2 1}}$ & $\underline{\mathbf{2 0 2 0}}$ & $\underline{\mathbf{2 0 2 1}}$ \\
9.3 & 9.4 & 25.0 & 25.0 & 345.0 & 348.0 & 8.6 & 8.7 \\
10.6 & 10.6 & 26.0 & 28.0 & 375.0 & 378.0 & 9.8 & 10.6 \\
11.0 & 11.1 & 26.0 & 29.0 & 390.0 & 395.0 & 10.1 & 11.4 \\
11.2 & 11.3 & 26.0 & 30.0 & 395.0 & 400.0 & 10.3 & 12.0 \\
9.9 & 10.0 & 26.0 & 26.0 & 350.0 & 355.0 & 9.1 & 9.3 \\
10.4 & 10.5 & 26.0 & 27.0 & 368.0 & 370.0 & 9.6 & 9.9 \\
10.6 & 10.7 & 27.0 & 28.0 & 372.0 & 375.0 & 10.0 & 10.5 \\
11.2 & 11.4 & 26.0 & 30.0 & 390.0 & 395.0 & 10.1 & 11.8 \\
12.6 & 12.7 & 26.0 & 32.0 & 405.0 & 408.0 & 10.5 & 13.0 \\
12.9 & 13.0 & 26.0 & 33.0 & 408.0 & 410.0 & 10.6 & 13.4 \\
0.4 & 0.3 & NS & 1.0 & 8.7 & 8.5 & 0.3 & 0.6 \\
\hline
\end{tabular}

Similar results were announced during 2020 and 2021 seasons. The enhancing effect of chitosan on uptake of water and different nutrients surely reflected on enhancing the biosynthesis of plant 
pigments and nutrients (Hadwiger et al., 2002). The promotion effect of chitosan on leaf chemical composition was supported by (Hadwiger et al., (2002); Ewaise, et al., (2006) on sugar beet; Xu et al., (2007); Hadwiger, (2013); Saied and Radwan, (2017)on Succary mango treesand Khalil, (2021) on Flame seedless grapevines.

The percentage of berry setting, yield and cluster weight:

Data concerning the effect of single and combined applications of chitosan and turmeric extract on the percentage of berry setting, yield and cluster weight of Flame seedless grapevines during 2020 and 2021 seasons are shown in Table (5). The evident from the obtained data that supplying the vines with chitosan at 0.025 to $0.1 \%$ and/ or turmeric extract at 0.1 to $0.3 \%$ significantly was followed by improving berry setting $\%$, yield expressed in weight (kg.) and number of cluster per vine and cluster weight relative to the control treatment.

There was a progressive promotion on these parameters with increasing concentrations of each material. Significant differences on these parameters were observed between all concentrations and materials except among the higher two concentrations of each material, therefore from economical point of view it is necessary to use the

\section{The percentage of berry colouration:}

Table (6) show the effect of single and combined applications of chitosan and turmeric extract on the percentage of berry colouration of Flame seedless grapevines during 2020 and 2021 seasons.
The higher content of these plant extracts from nutrients could explain the present results (Giovanni et al., 2012). Also, these results are in harmony with these obtained by Abdelaal and Aly (2013) on Ruby seedless grapevines, Abada, (2014) on Thompson seedless grapevines; Osman, (2014) on Superior grapevines and Uwakiem, (2014) on Thompson seedless grapevines.

material (Chitosan and Turmeric extract). Combined were favourable than using each material alone in this respect. Using chitosan significantly preferable than using turmeric extract in improving berry setting $\%$ yield and cluster weight.

From economical point of view using chitosan at $0.05 \%$ and turmeric extract at $0.2 \%$ resulted in the highest yield. Under such promised treatment yield per vine reached $10.6,13.4 \mathrm{~kg}$ during both seasons, respectively. The untreated vine gave the lowest yield reached $(8.6$ and $8.7 \mathrm{~kg})$ during both seasons, respectively.

The percentage of increment on the yield due to application of the previous treatment over the check treatment reached 23.3 and $54.0 \%$ during both seasons, respectively. These results were nearly the same during both seasons. The promoting effect of chitosan on berry setting, yield and cluster weight was emphasized by Ab-delaal et al., 2012and Khalil, (2021) on Flame seedless grapevines.

It is revealed from the obtained data that subjecting Flame seedless grapevines to chitosan at 0.025 to $0.1 \%$ and/ or turmeric extract at 0.1 to $0.3 \%$ significantly enhanced berry colouration relative to the control treatment.

Table (6): Effect of single and combined application of chitosan and turmeric extract on the percentages of berry colouration and some physical characteristics of the berry of Flame seedless grapevines during 2020 and 2021 seasons

Treatment

Control

Spraying chitosan at $0.025 \%$

Spraying chitosan at $0.05 \%$

Spraying chitosan at $0.1 \%$

Spraying turmeric extract at $0.1 \%$

Spraying turmeric extract at $0.2 \%$

Spraying turmeric extract at $0.3 \%$

Spraying chitosan at $0.025 \%+$ turmeric extract at $0.1 \%$.

Spraying chitosan at $0.05 \%+$ turmeric extract at $0.2 \%$.

Spraying chitosan at $0.1 \%+$ turmeric extract at $0.3 \%$

New L.S.D. at $5 \%$

\begin{tabular}{lllllllll}
$\begin{array}{c}\text { Berry } \\
\text { colouration \% }\end{array}$ & \multicolumn{2}{c}{$\begin{array}{c}\text { Av. Berry } \\
\text { weight (g.) }\end{array}$} & \multicolumn{2}{c}{$\begin{array}{c}\text { Av. Berry } \\
\text { length (cm) }\end{array}$} & \multicolumn{2}{c}{$\begin{array}{c}\text { Av. Berry } \\
\text { diameter }\end{array}$} \\
\hline$\underline{\mathbf{2 0 2 0}}$ & $\underline{\mathbf{2 0 2 1}}$ & $\underline{\mathbf{2 0 2 0}}$ & $\underline{\mathbf{2 0 2 1}}$ & $\underline{\mathbf{2 0 2 0}}$ & $\underline{\mathbf{2 0 2 1}}$ & $\underline{\mathbf{2 0 2 0}}$ & $\underline{\underline{\mathbf{2 0 2 1}}}$ \\
70.0 & 70.8 & 3.32 & 3.35 & 2.14 & 2.15 & 1.89 & 1.90 \\
77.1 & 78.0 & 3.55 & 3.60 & 2.23 & 2.24 & 2.02 & 2.04 \\
80.2 & 81.9 & 3.71 & 3.74 & 2.31 & 2.32 & 2.08 & 2.09 \\
82.2 & 82.8 & 3.76 & 3.77 & 2.33 & 2.34 & 2.09 & 2.10 \\
73.2 & 74.0 & 3.40 & 3.41 & 2.16 & 2.17 & 1.92 & 1.93 \\
76.5 & 77.0 & 3.52 & 3.55 & 2.21 & 2.22 & 1.99 & 1.99 \\
77.0 & 78.2 & 3.56 & 3.58 & 2.22 & 2.24 & 2.02 & 2.03 \\
83.0 & 83.5 & 3.75 & 3.76 & 2.33 & 2.34 & 2.09 & 2.09 \\
90.0 & 91.2 & 3.84 & 3.85 & 2.37 & 2.38 & 2.13 & 2.14 \\
92.0 & 93.1 & 3.88 & 3.90 & 2.38 & 2.40 & 2.14 & 2.15 \\
0.8 & 0.9 & 0.04 & 0.05 & 0.05 & 0.06 & 0.03 & 0.04 \\
\hline
\end{tabular}

Using chitosan was significantly superior than using turmeric in enhancing berry colouration.A mixture of chitosan and turmeric extract was significantly preferable in enhancing berry colouration than using material alone. Meaningless 
promotion on berry colouration was observed among the higher two concentrations of each material.

A progressive promotion was noticed with increasing concentrations of each material. The berry coloration reached the highest values $(92.0,93.1 \%)$ in the vines that received both materials together at the higher concentration. The lowest berry colouration $(70.0,70.8 \%)$ was occurred on the untreated vines during both seasons, respectively. These results were true during both seasons.

The results of berry colouration are in the same line with the present results concerning the effect of Some physical and chemical characteristics of the berry:

Data in Tables $(6,7)$ show the effect of single and combined applications of chitosan and turmeric chitosan on enhancing berry colouration (Hadwigeret al., 2002, Ewaise et al., (2006) on sugar beet ; Xu et al., 2007 and Khalil, (2021) on Flame grapevines.

The higher control of these plant extracts from nutrients, vitamins, hormones and amino acids in balanced rate (Kamra et al., 2012).

These results are in accordance with those obtained by (Abdelaal and Aly, (2013) and Gad El- Kareem and Abd El- Rahman, (2013) On Ruby seedless grapevines

extract on berry weight and dimensions (length and diameter), TSS $\%$, total sugars $\%$, total acidity $\%$ and TSS/ acid ratio in the berry of Flame seedless grapevines during 2020 and 2021 seasons.

Table (7): Effect of single and combined application of chitosan and turmeric extract on some chemical characteristics of berry of Flame seedless grapevines during 2020 and 2021 seasons

\section{$\underline{\text { Treatment }}$}

Control

Spraying chitosan at $0.025 \%$

Spraying chitosan at $0.05 \%$

Spraying chitosan at $0.1 \%$

Spraying turmeric extract at $0.1 \%$

Spraying turmeric extract at $0.2 \%$

Spraying turmeric extract at $0.3 \%$

Spraying chitosan at $0.025 \%+$

turmeric extract at $0.1 \%$.

Spraying chitosan at $0.05 \%+$ turmeric

extract at $0.2 \%$.

Spraying chitosan at $0.1 \%+$ turmeric extract at $0.3 \%$

New L.S.D. at $5 \%$

\begin{tabular}{cccccccc}
\multicolumn{2}{c}{ T.S.S. \% } & \multicolumn{2}{c}{$\begin{array}{c}\text { Total sugars } \\
\text { \% }\end{array}$} & \multicolumn{2}{c}{$\begin{array}{c}\text { Total acidity } \\
\text { \% }\end{array}$} & \multicolumn{2}{c}{$\begin{array}{c}\text { T.S.S. / acid } \\
\text { ratio }\end{array}$} \\
\hline$\underline{\mathbf{2 0 2 0}}$ & $\underline{\mathbf{2 0 2 1}}$ & $\underline{\mathbf{2 0 2 0}}$ & $\underline{\mathbf{2 0 2 1}}$ & $\underline{\mathbf{2 0 2 0}}$ & $\underline{\mathbf{2 0 2 1}}$ & $\underline{\mathbf{2 0 2 0}}$ & $\underline{\mathbf{2 0 2 1}}$ \\
18.2 & 18.4 & 16.1 & 16.5 & 0.690 & 0.690 & 26.3 & 26.7 \\
19.2 & 19.4 & 17.2 & 17.5 & 0.650 & 0.650 & 29.5 & 29.8 \\
20.2 & 20.5 & 18.1 & 18.6 & 0.625 & 0.620 & 32.3 & 33.1 \\
20.6 & 20.7 & 18.5 & 18.7 & 0.615 & 0.610 & 33.5 & 33.9 \\
18.4 & 18.5 & 16.5 & 16.4 & 0.680 & 0.678 & 27.1 & 27.3 \\
18.8 & 18.9 & 16.9 & 16.9 & 0.660 & 0.655 & 28.5 & 28.9 \\
19.3 & 19.4 & 17.4 & 17.3 & 0.655 & 0.650 & 29.5 & 29.8 \\
20.6 & 20.7 & 18.5 & 18.6 & 0.620 & 0.615 & 33.2 & 33.7 \\
21.0 & 21.2 & 19.0 & 19.1 & 0.590 & 0.585 & 35.6 & 36.2 \\
21.2 & 21.3 & 19.1 & 19.2 & 0.585 & 0.580 & 36.2 & 36.7 \\
0.3 & 0.4 & 0.3 & 0.3 & 0.015 & 0.016 & 0.9 & 0.9 \\
\hline
\end{tabular}

It is clear from the obtained data that treating Flame seedless grapevines three times with chitosan at $0.025,0.05$ and $0.1 \%$ and / or turmeric extract at $0.1,0.2$ and $0.3 \%$ significantly was favourable than the control treatment in improving quality of the berry in terms of increasing weight, length and diameter of berry, TSS\%, total sugars \% and TSS/ acid ratio and decreasing total acidity $\%$ relative to the check treatment. The promotion on quality of the berry was related to the increase in concentrations of chitosan and turmeric extract without significant promotion among the higher two concentrations of chitosan and turmeric extract. Using chitosan significantly was preferable than using turmeric extract in enhancing physical and chemical properties of the berry .These results regarding the promoting effect of chitosan on berry quality are in harmony

\section{REFERENCES}

Abada, M.A.M. 2014. A comparative study for the effect of green tea extract and some antioxidants on Thompson seedless grapevines. International with those obtained by (Hadwiger et al., 2002; Ewaise et al., (2006); Xu et al., 2007; Hadwiger, 2013; Saied and Radean, (2017) on Succary mangoand Khalil, (2021) on Flame seedless grapevines.

The beneficial effects of these plant extracts on advancing maturity explained these results. This effect was attributed to the higher content of these plant extracts on sugars, boron, magnesium, sulphur and essential amino acids (Dhekney, 2016).

These results are in concordance with those obtained by (Abdelaal and Aly, 2013 and Gad ElKareem;Abd El- Rahman, (2013) on Ruby grapevines;Abada(2014) on Thompson seedless grapevines and Ahmed et al., 2016) on Superior grapevines.

Journal of Plant \& Soil Science. 3 (10): 13331342.

Abdelaal, A.M.H.A., and Aly, M.M. 2013. The synergistic effects of using turmeric with some antioxidants on growth, vine nutritional status and 
productivity of Ruby seedless grapevines. Hort. Science Journal of Suez Canal Univ. 1: 305-308.

Ahmed, F.F., and Morsy, M.H. 1999. A new method for measuring leaf area in different fruit species. Minia J. of Agric. Res. 8 Develop. 19: 97-105.

Ahmed, F.F., Abada, M.A.M., and Meckawy, A.Y.H. 2016. Response of Thompson seedless grapevines to turmeric extract and GA; foliar application after berry setting. J. Biol Chem. Environ- Sci. 1(1): 319-329.

Association of Official Agricultural Chemists. 2000. Official Method of Analysis (A.P.A.C.) 15" Ed., Published by A.O.A.C. Washington, D.C, U.S.A. 490-510.

Chapman, H.D., and Pratt, P.P. 1987. Method of Analysis for Soils, Plants and Water. Univ. of California. Division of Agric. Sci. 172-173.

Dhekney, S.A., 2016. Encyclopedia of food and health. Academic Press, Oxford, 261-265.

Dias, A.M.A., Cortez, A.R., Barsan, M.M., Santos, J.B., Brett, C.M.A., and De Sousa, H.C. 2013. development of greener multiresponsive chitosan biomaterials doped with biocompatible ammonium Ionic liquids, ACS sustainable chem. Eng. 1(11): 1480-1492.

Eweis, M., Elkholy, S.S., and Elsabee, M.Z. 2006. Antifungal efficacy of chitosan and its thiourea derivatives upon the growth of some sugar beet pathogens. International Journal of Biological Macromolecules. 38(1), 1-8.

Gad El-Kareem, R.M., and Abd El- Rahman, I.M.M. 2013. Response of Ruby seedless grapevines to foliar application of seaweed extract, salicylic acid and roselle extract. 11ort. science Journal of Suez Canal Univ. 1: 294- 303.

Giovanni, B., Guide, F., Angelo, G., Pierluigi , C., and Barbara, C. 2012. Toxicity of some essential oil formulations against the Mediterranean fruit fly ceratitiscapitata (Wiedemann) (DipteraTephritida, e.) crop protection. 42: 223229.

Hadwiger, L.A. 2013. Multiple effects of chitosan on plant systems. Solid science or hype. Plant Sci. 208: 42-49.

Hadwiger, L.A., Klosterman, S.J., and Choi, J.J. 2002. The mode of action of chitosan and its oligomers in inducing plant promoters and developing disease resistance in plants. Advances in chitin science. 5, 452-457.

Jabeen, N., and Ahmad, R. 2013. The activity of antioxidant enzymes in response to salt stress in safflower (Carthamustinctorius, L.) and sunflower (Helianthus annuus L.) seedlings raised from seed treated with chitosan. J. Sci. Food Agric. 93(7): 1699-1705.

Karma, D.N., Agarwal, N., Sokthivel, P.C., and Chiaudhary, L.C. 2012. Garlic as a ruman modifier for eco- friendly and economic livestock production. Journal of Applied animal Research. 40(2): 90-96.
Khalil, M.A. 2021. Studies on the effect of chitosan on productivity of Flame seedless grapevines Ph.D. Thesis Fac, of Agric. Al- Azhar UnivAssiut branch.

Lane, J.H., and Eynon, L. 1965. Determination of reducing Sugars by means of Fehling's solution with methylene blue as indicator A.O.AC. Washington D.C. U.S.A.: 100- 110.

Lin, W., Hu, X., Zhang, W., Rogers, W.J., and Cai, W. 2005. Hydrogen peroxide mediates defence responses induced by chitosan of different molecular weights in rice. Journal of plant physiology. 162(8): 937-944.

Liu, J., Tian, S., Meng, X., and Xu, Y. 2007. Effects of chitosan on control of postharvest diseases and physiological responses of tomato fruit. Postharvest Biology and Technology. 44(3): 300306.

Mead, R., Curnow, R. N., and Harted, A. M. 1993. Statistical methods inAgricultural and Experimental Biology. 2"d Ed. Chapman \& Hall, London. 1-1: 10-44.

Mondal, M.M.A., Malek, M.A., Puteh, A.B., Ismail, M.R., Ashrafuzzaman, M., and Naher, L. 2012. Effect of foliar application of chitosan on growth and yield in orka. Aust J. crop Science. 6(5): 918-921.

Osman, M.M. 2014. Response of Superior grapevines grown under hot climates to rest breakages. M. Sc. Thesis Fac. of Agric. Minia Univ. Egypt.

Parl, P.J., Je, J.Y., and Kim, S.K. 2004. Free radical scavenging activities of differently deacetylated chitosan using an ESR Spectrometer. Carbohydrate polymers. 55 (1): 17-22.

Peter, K.V. 1999. Information on turmeric and ginger Indian species. $6(2,3): 12-14$.

Pongrayoon, W., Rotrakul, S., Pichayangkura, R., and Chadchawan, S. 2013. The role of hydrogen peroxide in chitosan induced resistance to osmotic stress in rice (Oryza- sativa L.) Plant Growth Regul. 70 (2): 159-173.

Saied, H.H.M., and Radwan, E.M.A. 2017. Insight into the effect of chitosan on growth and fruiting of succary mango trees. J. Product. Dev. 22 (3): 781-793.

Shao, X.F., Cao, B., Xu, F., Xie, S., Yu, D., and Wang, H. 2015. Effect of postharvest application of chitosan combined with clove oil against citrus green mold. Postharvest Biol. Tehcnol. 99: 37-43.

Shiyou, L., Yuan, W., Deng, G., Wang-Ping, Yang.P., and Agaarwal, B. 2011. Chemical composition and product quality control of turmeric (Curcuma Longa L.) Stephen F. Austin state Univ. SFA sholar works.

Singh, D.V., Srivastava, G.C., and Abdin, M.S. 2001. Amelioration of negative effect of water stress in Gassiaangustifolia by benzyladenine and/ or ascorbic acid. Bidoyiaplantarum, 44 (I): 141- 143.

Summer, M.E. 1985. Diagnosis and Recommendation integrated system (DRIS) as a guide to orchard fertilization Hort. 55 (8): 7502. 
Uwakiem, M.Kh. 2014. The synergistic effect of spraying some plant extracts with some macro and micro nutrients of Thompson seedless grapevines.International Journal of Plant \& Soil Science. 3(10): 1290-1301.

Von- Wettstein, D.V. 1957. Chlorophyll- Ithale undersubmikrosphpischeformiuechrel der plastidenExperimental cell, Drp. Trop. Res. Amer. Soc. Hort. Sci. 12: 427- 433.

Wilde, S.A., Corey, R.B., lyer, I.G., and Voigt, G.K. 1985. Soil and plant analysisfor tree culture. 3rd
Ed.Oxford and IBH publishing co., New Delhi India. : 529-546.

Wojdyla, A.T. 2001. Chitosan in the control of rose disease 6- year- trials. Bull polish Academy. Sci. Biolog, Sci. 49(3): 233-252.

$\mathrm{Xu}$, J.1., Zhao, X., Han, X., and Du, Y. 2007.Antifungal activity of oligochitosan against phytophthoracapsici and other plant pathogenic fungi in vitro pesticide Biochemistry and physiology. 87(3): 220-228.

\footnotetext{
الملخص العربى

تأثير رش الشيتوزان ومستخلص الكركم عى الاثمار فى العنب القليم سبدلس

محمود محمد رفاعى' ، أحمد عبدالفتاح السيد محمد سليم *

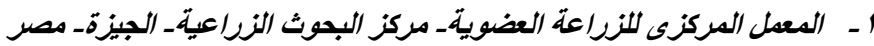

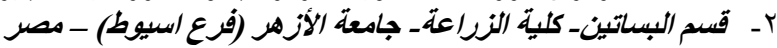

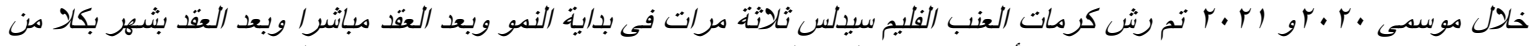

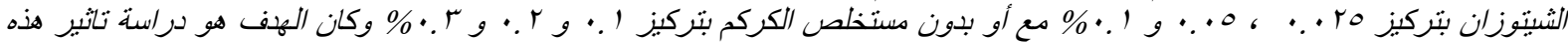

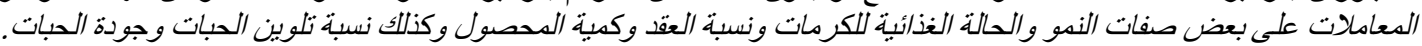

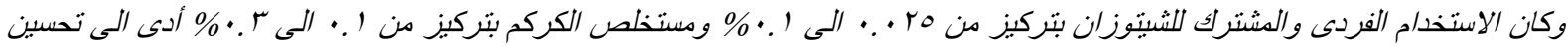

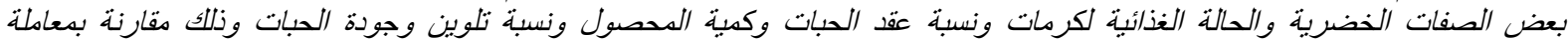
الكونترول.

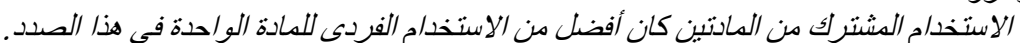

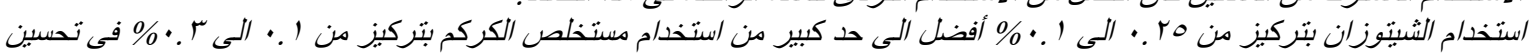

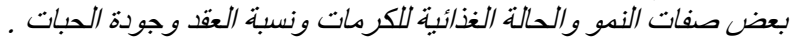

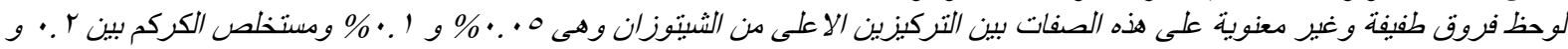
$\% \cdot \%$

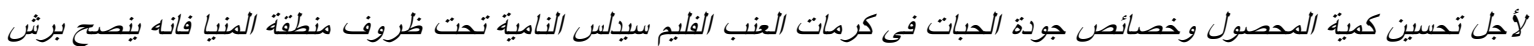

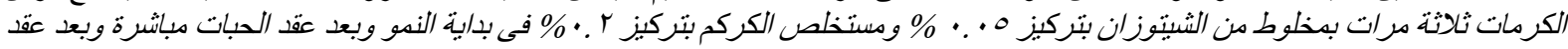

